\title{
CAMBRIDGE
}

The Political

Economy of

Nasserism

A Study of Employment and Income Distribution Policies in Urban

Egypt, 1952-72

Mahmoud Abdel-Fadil

This book emphasizes employment and income redistribution policies, particularly with regard to the urban sector, pursued under the Nasser regime.

\section{Muslim Society}

\section{Ernest Gellner}

An examination of why contemporary Islam is able to support traditional and conservative regimes as well as revolutionary ones.

\section{Saladin: The Politics} of the Holy War Malcolm Cameron Lyons and David Jackson

This detailed study of Saladin is based on hitherto neglected Arabic sources.

\section{Heart-Beguiling} Araby

\section{Kathryn Tidrick}

A colorful account of British travelers and explorers, concentrating on the liveliest figures, from Sir Richard Burton to T.E. Lawrence.

\section{The Arab Predicament}

Arab Political Thought and Practice Since 1967

Fouad Ajami

Ajami examines not only the maior political ideas and trends at work in recent years, but also the performance and fate of the dominant political order.

\section{Early Muslim Dogma A Source-Critical Study Michael Cook}

A study of a group of religious epistles that are the earliest sources for the history of Muslim theology.

\section{The African Middle Ages 1400-1800} Roland Oliver and Anthony Atmore A history of the whole continent of Africa from 1400 to 1800 .

\section{Africa Since 1800} Third Edition

Roland Oliver and Anthony Atmore

\section{Cambridge University Press}




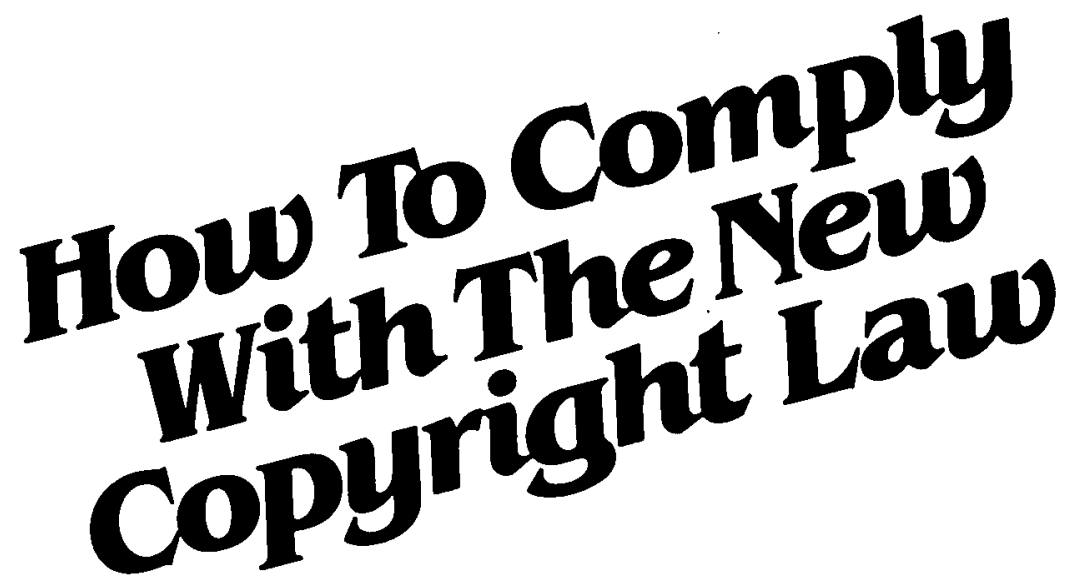

Libraries everywhere have found the easy way to fill photocopy requests legally and instantly, without the need to seek permissions, from this and over 3000 other key publications in business, science, humanities, and social science.

Participation in the Copyright Clearance Center (CCC) assures you of legal photocopying at the moment of need. You can:

Fill requests for multiple copies, interlibrary loan (beyond the CONTU guidelines), and reserve desk without fear of copyright infringement.

Supply copies simply and easily from registered publications. The CCC's flexible reporting system accepts photocopying reports and returns an itemized invoice. You

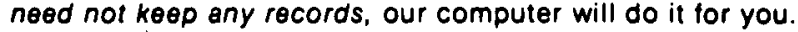

The Copyright Clearance Center is your one-stop place for on-the-spot clearance to photocopy for internal use. You will never have to decline a photocopy request or wonder about compliance with the law for any publication registered with the CCC.

For more information, just contact:

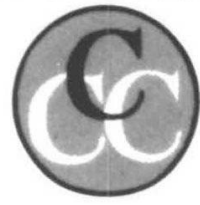

\section{Copyright Clearance Center}

21 Congress Street

Salem, Massachusetts 01970

(617) $744-3350$

a not-for-profit corporation 


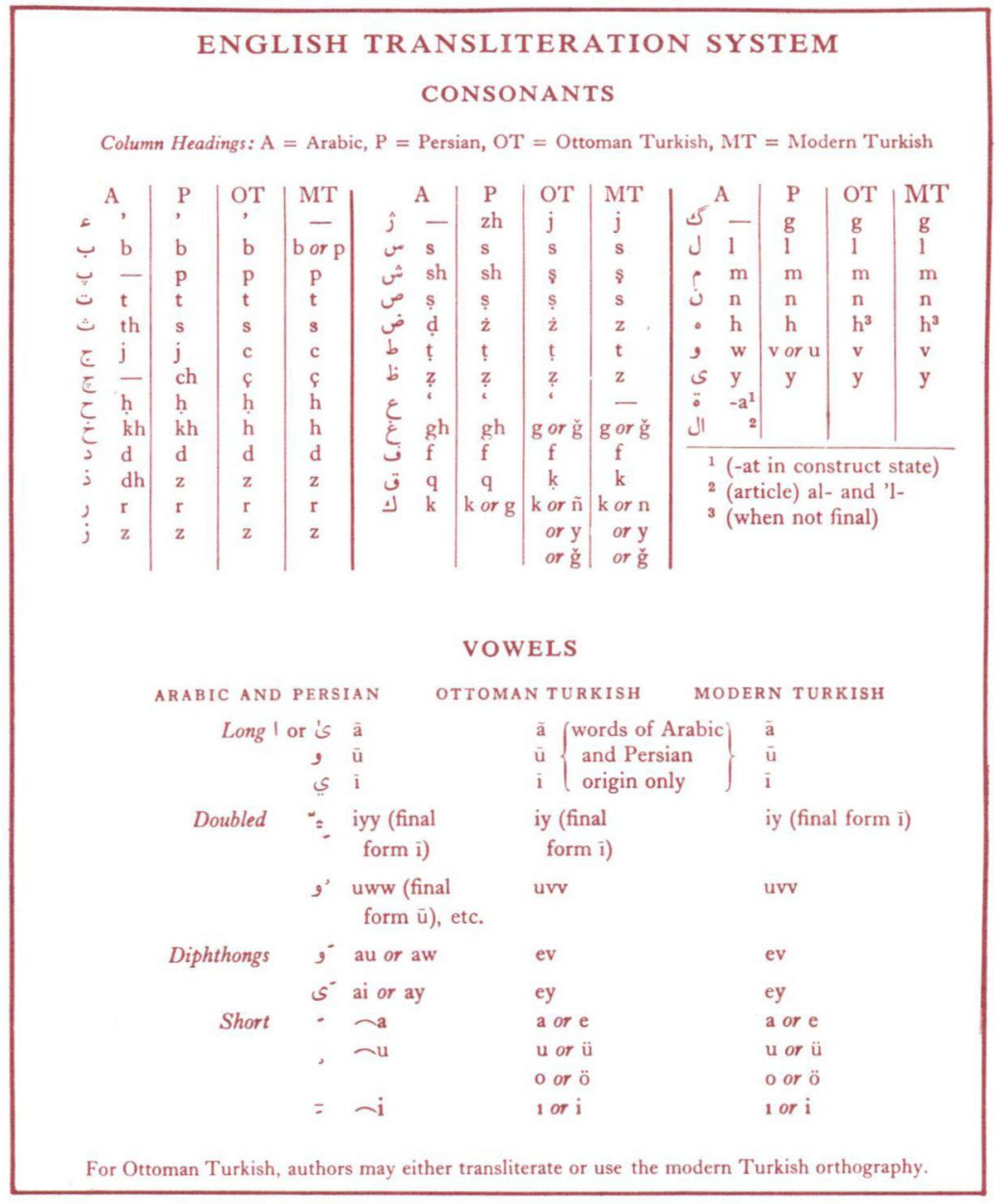

Notes should be numbered consecutively and grouped together at the end of the text. They should be typed paragraph style (each new note begins a new paragraph), double-spaced between lines as well as between entries. The style of citations in notes should conform with the following examples:

1 E. Ashtor, A Social and Economic History of the Near East in the Middle Ages (Berkeley, 1976), pp. 29-31.

2 S.D. Goitein, A Mediterranean Society, Vol. I, Economic Foundations (Berkeley, 1967), p. 193.

3 Bruce M. Russett, "Delineating International Regions," in J. David Singer, ed., Quantitative International Politics (New York, 1968), pp. 45-68.

4 B. Shoshan, "Grain Riots and the 'Moral Economy' in Egypt 1350-1517," Journal of Interdisciplinary History, 10, 3 (Winter, 1980), 459-478.

When references to the same work follow without interruption use ibid. When references to the same work follow after interruption by other notes, use the author's last name and a short form of the title.

Figures (charts, graphs, and other artwork) should be in camera-ready form; they cannot be redrawn by the printer. Captions should be provided, and preferred placement of figures indicated in manuscript.

Copyediting and proofreading. The publishers reserve the right to copyedit and proof all articles accepted for publication. Authors will review their copyedited manuscripts only if changes have been substantial. Page proofs of articles will be sent to authors for correction of typographical errors only.

General. Authors receive 50 offprints of their article without charge; additional copies may be purchased if ordered at proof stage. Submission of an article implies that it has not been published elsewhere. Authors are responsible for obtaining written permission to publish material for which they do not own the copyright. Contributors will be asked to assign their copyrights, on certain conditions, to Cambridge University Press. Books for review should go to the Review Editor for the appropriate subject area (see inside front cover for addresses), or they may be sent to the Editor (Afaf Lutfi al-Sayyid-Marsot, Gustave E. von Grunebaum Center for Near Eastern Studies, University of California, Los Angeles, CA 90024) for forwarding. 


\section{CONTENTS}

Calvin H. Allen, Jr. The State of Masquat in the Gulf and East Africa, 1785-1829

ROBIN BARLOW Economic Growth in the Middle East, 1950-1972

Donald C. Mead Small Industries in Egypt: An Exploration of the Economics of Small Furniture Producers

Sheila K. Webster Women, Sex, and Marriage in Moroccan Proverbs

RifaAt Ali Abou-El-HaJ The Social Uses of the Past: Recent Arab Historiography of Ottoman Rule

MARK N. CoOper The Demilitarization of the Egyptian Cabinet

\section{The Middle East Studies Association of North America, Inc.}

This association was founded in 1966 in order to promote high standards of scholarship in the field of Middle Eastern studies and to facilitate communication among scholars through meetings and publications. In addition to sponsoring the Journal, which is published for the Association by the Cambridge University Press, MESA publishes a Bulletin periodically, holds an Annual Conference, and provides other professional services for its members from time to time. Individuals interested in becoming members should write to: Headquarters and Secretariat, Department of Oriental Studies, University of Arizona, Tucson, AZ 85721. Fees are as follows: Full and associate members $\$ 40.00$; students $\$ 18.00$. Fee includes subscription to International Journal of Middle East Studies, and to the MESA Bulletin and MESA Newsletter.

Members of the British Society for Middle Eastern Studies may subscibe to International Journal of Middle East Studies at a special rate of two-thirds of the present regular subscription price. Enquires concerning membership in BRISMES should be sent to the Secretary, Dr. D. Hopwood, St. Antony's College, Oxford, England.

\section{Notes for Contributors}

Contributions and Editorial Correspondence should be sent to the Editor, Afaf Lufti al-Sayyid-Marsot, Gustave E. von Grunebaum Center for Near Eastern Studies, University of California, Los Angeles, CA 90024. Authors should reserve one full copy of their manuscript for use in correcting proofs. Articles must be in English, should not exceed 12,000 words, and should be accompanied by a short summary. Spelling, capitalization, and punctuation must be consistent within each article and conform with the latest edition of $A$ Manual of Style (University of Chicago Press).

Preparation of Manuscript. A title page should be prepared carrying the article title, auxiliary short title (not over 50 characters), author's full name (in the form preferred for publication), and author's affiliation (including mailing address). The entire manuscript (including notes) should be typed double-spaced on $81 / 2 \times 11$ inch or A4 paper, with margins set to accommodate 70 characters per line and 25 lines per page, and should not exceed 43 typed pages. Manuscript pages should be numbered consecutively.

Loanwords and Foreign Words. Loanwords (accepted English words such as ulama, alim, Shic ite, sheikh, qadi, Sunni, and others) should be spelled in accordance with the first choice presented in Webster's Third New International Dictionary. Foreign words (not yet loanwords) must conform with the Journal's transliteration system; they should be italicized and defined at first use (and not italicized thereafter). Diacritics, except for ains and hamzas, should be omitted except where they are imperative to the argument. Authors who do use diacritics and transliteration have the total responsibility for consistency and accuracy in manuscript. 